\title{
CAR OWNERSHIP MODELS IN IRAN: A REVIEW OF METHODS AND DETERMINANTS
}

\author{
Maryam Shaygan ${ }^{1}$, Amirreza Mamdoohi ${ }^{2}$,Houshmand E. Masoumi ${ }^{3}$ \\ ${ }^{1,2}$ Tarbiat Modares Univesity \\ Jalal Ale Ahmad Highway, P.O.Box 14115-111, Tehran, Iran \\ le-mail: maryam.shaygan@modares.ac.ir \\ ${ }^{2}$ e-mail: armamdoohi@modares.ac.ir \\ ${ }^{3}$ Technische Universität Berlin, Center for Technology and Society \\ Hardenbergstr. 16-18, 10623 Berlin, Germany \\ e-mail:masoumi@tu-berlin.de
}

\begin{abstract}
The achievement of sustainable transportation and the desire to reduce car ownership are important aspects of urban planning, especially in developing countries. This paper presents an overview of researches and studies conducted on car ownership to find the knowledge gap and neglected modelling methods that should be employed in the further researches in Iran as one of the Middle East countries. It is found that car ownership models have under gone modification and improvement from regression models towards discrete choice models, although more improvement is necessary and underway. Lack of reliable aggregate and disaggregate data regarding public transport, land use, behavioural and socioeconomic variables particularly for small cities is prominent. To fill the gap, more descriptive and analytical researches and more complex modelling methods and variables need be delved.
\end{abstract}

Keywords: Urban transportation planning, car ownership models, The Middle East, Iran

\section{Introduction}

Owning a car and using it play a significant role in changing the quality of human life (Sinha, 2003). Creating identity and tranquillity and easy access for car owners are among the most important reasons that increased car ownership in the last century (Loukopoulos, 2005; Jensen, 1999; Ellaway et al., 2003). One of the main sources of government revenue is car owners and users (Allanson, 1982) although increasing private vehicle ownership causes more energy consumption (Chiou et al., 2009), disturbance of ecosystem balance (Loukopoulos, 2005), excessive car trips and congestion, especially if the transportation infrastructures are inadequate (Goodwin, 1986). Furthermore, an increase in private car use will decrease public transportation patronage since they are substitutes (Kermanshah and Kitamura, 1995; Paulley et al., 2006). Adverse social, economic and environmental consequences (Loukopoulos, 2005) of car ownership growth has caused the government, vehicle manufacturers, environmental protection groups and transport planners pay a special attention to the level of car ownership (Kumar and Rao, 2006).

Furthermore, daily car use of individuals and households is affected by car ownership, because by owning a car, people can be enabled to travel longer distances (Bagley and Mokhtarian, 2002). That is why average car use among households, who own several cars seems higher than the corresponding value in the households without car (Dieleman et al., 2002). Therefore, Four-step transportation planning process and urban land use models have been linked by car ownership models (Lerman, 1979). It is the main variable in predicting trip generation (Meurs, 1990) and choice models (Domencich and McFadden, 1972).

In most studies, car ownership models explain the behaviour of passengers in industrialized countries, particularly North America, Western Europe and Australia. Few studies have been done for developing countries in Middle East, and thus effective factors and their quantitative impacts in these countries are still less known.

The inclusion of car and large growth in car use at Iran as one of the largest countries located in the Middle East, bring an enormous change on the modal split of citizens through industrialization. Iran is almost following a motorization trend faster than most of the developed countries (Table 1). Because 
heavy automotive use is associated with negative consequences mentioned above, it has become a critical issue in the country. Undoubtedly, applying the same policies of developed countries to change modal split in Iran, would conclude different results even when there are similarities on the behaviour.

Table 1. Car Ownership rate increase in Selected Middle East and developed countries

\begin{tabular}{|c|c|c|c|c|}
\hline \multirow{3}{*}{ Country } & \multicolumn{3}{|c|}{ Car per 1000 inhabitants } & \multirow{3}{*}{ Annual Growth Rate ${ }^{* * *}$} \\
\hline & $2002^{* * *}$ & 2010 & $2030^{* * *}$ & \\
\hline & \multicolumn{3}{|c|}{ ( Unless Indicated Differently) } & \\
\hline Iran & $69^{*}$ & $175^{*}$ & $679^{*}$ & $4.9 \% *$ \\
\hline Austria & 659 & $585^{2}$ & 803 & $0.9 \%$ \\
\hline Belgium & 520 & 559 & 636 & $0.7 \%$ \\
\hline Switzerland & 559 & $573^{2}$ & 741 & $1.0 \%$ \\
\hline Germany & 586 & $588^{2}$ & 705 & $0.7 \%$ \\
\hline Denmark & 430 & 480 & 715 & $1.8 \%$ \\
\hline Spain & 564 & $593^{2}$ & 795 & $1.2 \%$ \\
\hline Finland & 488 & $551^{2}$ & 791 & $1.7 \%$ \\
\hline France & 576 & $578^{* *}$ & 779 & $1.1 \%$ \\
\hline Great Britain & 515 & 519 & 685 & $1.0 \%$ \\
\hline Grees & 422 & 537 & 725 & $2.0 \%$ \\
\hline Hungry & 306 & 345 & 745 & $3.2 \%$ \\
\hline Ireland & 472 & $513^{1}$ & 812 & $2.0 \%$ \\
\hline Iceland & 672 & $747^{2}$ & 768 & $0.5 \%$ \\
\hline Italy & 656 & 682 & 781 & $0.6 \%$ \\
\hline Luxemburg & 716 & $741^{2}$ & 706 & $-0.1 \%$ \\
\hline Netherlands & 477 & 528 & 593 & $0.8 \%$ \\
\hline Norway & 521 & $591^{2}$ & 805 & $1.6 \%$ \\
\hline Poland & 370 & 580 & 746 & $2.5 \%$ \\
\hline Sweden & 500 & 520 & 777 & $1.6 \%$ \\
\hline USA & 812 & $809^{2}$ & 849 & $1.1 \%$ \\
\hline Canada & 581 & $607^{1}$ & 812 & $1.8 \%$ \\
\hline Australia & 632 & $723^{3}$ & 772 & $0.7 \%$ \\
\hline Japan & 599 & 566 & 716 & $0.6 \%$ \\
\hline Newziland & 612 & $708^{2}$ & 786 & $0.9 \%$ \\
\hline Egypt & 38 & 45 & 142 & $4.9 \%$ \\
\hline Israel & 303 & $358^{3}$ & 454 & $1.5 \%$ \\
\hline Syria & 35 & 73 & 80 & $3.0 \%$ \\
\hline
\end{tabular}

${ }^{1}$ Data available for 2009 derived from World Bank.

2 Data available for 2011 derived from World Bank.

${ }^{3}$ Data available for 2014 Australian Bureau of Statistics, 2013.

* Source: Comprehensive Transportation Study of Iran, 2008.

** Source: CCFA Information Press.

*** Source: Dargay et al., 2007.

Due to the necessity of having a more in-depth understanding of decisions behind owning a car in Iran, this paper presents a discussion on the available literature of the applied car ownership models and a review has been done on various case studies, methods and significant variables. By specifying the main gaps in car ownerships researches and highlighting well analysis, not only transport planners can find out 
the main cause of inefficiency of researches which are done in the country, but also more complete methodologies and topics for further studies will be recommended.

\section{Car Ownership Modelling in the International Context}

The models found in the literature have been classified into different types (Jong et al., 2004). Aggregate models are simple and are generally used for administrative purposes and do not need extensive data. They can be divided into two categories: cross sectional aggregate models and time series aggregate models. In cross sectional models, data from a particular moment in time with a geographical distribution, are often developed by using linear regression model (Tanner, 1963; Phang and Chin, 1990; Said, 1992). However, because of non-linear structure of car ownership and local variation review, this method does not provide desired results. Accordingly, Geographically Weighted Regression model was used (Clark, 2007). Time Series aggregate models, usually by using the S-shaped curve and the saturation level of vehicle ownership concept, developed over a period of time (Button et al., 1993; Ogut, 2004). Disaggregate models are newer than the aggregate models and they are developed in Household level. They often require a broader and more complete data. Generally, these models can be divided into three categories. Static and Semi- Dynamic models include Discrete Choice models such as Ordered Logit (Bhat and Pulugurta, 1998), Multinomial Logit (Bhat and Pulugurta, 1998; Ryan and Han, 1999; Potoglou and Kanarglou, 2008), Nested Logit (Dissanayake and Morikawa, 2002), Hierarchical Logit, Binary Logit (Whelan, 2007) and Poisson regression (Hsu et al., 2007). Dynamic models can be considered as a new approach to modelling in vehicle ownership when deciding on the issue of car ownership vehicle trade is an important independent variable in all types of these models (Gilbert, 1992; De Jong et al., 2009; Rashidi and Mohammadian, 2011).

There are a considerable number of car ownership research making the effective factors of car ownership partially clear, particularly in the higher-income countries i.e. the existing literature shows that the family income (Button et al., 1993; Dargay and Gately, 2001) is one of the most important factors that have an asymmetric (Dargay, 2001) effect on vehicle ownership. Residential density (Mogridge, 1967; Zhang et al., 2014), demographic structure (Whelan, 2007) and household socio-economic characteristics (Kain and Beesley, 1965; Potoglou and Kanaroglou, 2008) are the independent variables that describe car ownership in developed countries. In 2013, Stasko et al. observed that the increase in carsharing would be reduced car ownership by university students. Bento et al. (2005) concluded the transit supply and urban forms such as city shape does not affect the number of vehicles owned by the households. The results of the study done by McGoldrick and Caulfield (2015) showed that the negative impacts of the number of bus stations were still unclear in car ownership but the effect of rail availability was obvious. In The Netherlands, car ownership among young adults was the function of household composition and urbanization level. Two-parent families had more desire to have a car in compared with singles and couples. In addition, living in the high density and urban areas caused decreasing car ownership than the rural and suburb areas (Oakil et al., 2016). Matas and Raymond (2008) presented the car ownership growth over two decades in Spain. They found out a convenient public transport is an important factor in decreasing the tendency of families to own one or more vehicles. Income elasticity was variable and increased by car ownership reduction. The age of household members does not have a significant effect on car ownership.

\section{Car Ownership Modelling in Middle East}

Over the past six decades, several kinds of models of car ownership is made and they are still used in car ownership modelling to predict in developed and developing countries. Depending on the type and role of various factors, the type of model is chosen (Jong et al., 2004) in each country. Unfortunately, very little research has been done in the field of vehicle ownership in the Middle East. One of the first researches that was done, was the Manski's paper in 1983. He investigated with aggregate discrete choice models to analyze vehicle ownership in Israel. Car ownership in Kuwait, as a developing country, has been modelled by Said (1992), where household size, income and number of adults were selected as causal variables. Due to nationality, house type and household place of residence, some linear regression models were built and he found Kuwaiti households living in villas had higher car ownership rates than the others. Arab families' car ownership dependent on income and household size or number of adults. However, income was the only significant variable for Asian households. In 2001, a 
Gompertz function used by Dargay and Gately to predict the relationship between car ownership per capita and per-capita income, or Gross Domestic Production (GDP) in 85 countries over the next 25 years. He observed that the growth rate in the most Middle East countries will be slower than the others. In another compared that they did in 2007, they concluded that, in 2030, in contrast of car ownership in developed countries that they will have reached saturation, in most Asian countries, including the Middle East, only $15 \%$ to $45 \%$ of the saturation level will be acquired. Ögüt (2004) used three S-curve models including the logistic, power growth and Gompertz curve for the estimate of car ownership in Turkey. He chose Gross National Product per capita (GNPPC) and saturation level of car ownership as independent variables. The conclusion was that the logistic curve model gave the biggest car ownership level upon the forecast and difference between power growth and Gompartz model was minimal but their outputs were much closer to the reality than the logistic curve. In 2006, Ögüt applied Fuzzy regression analysis to explain car ownership. Four variables were chosen for analysis, including average family size, urban population, GNPPC and total length of roads $(\mathrm{Km})$. He overcame the intercorrelation problem associated with the independent variables. Azadeh et al. (2012) indicated that car ownership estimation and forecasting in complex and uncertain environments will be improved with an adaptive neural network-fuzzy linear regression approach. Thus the effects of politico-social, demographic and urban structure factors for the case of Iran were investigated by these intelligent methods. Begiawan et al. (2014) presented mode choice patterns for car ownership motivations among undergraduate students in Lebanon. They examined three types of data: sociodemographic characteristics, current transportation patterns, attitudes and perceptions, and norms. Cheap car purchase price, living with family, high average personal and family monthly income, low public transport quality, developing a sense of independence in person and high symbolic affective and arrogant impression rate that car gave were increased willingness to use car.

Table 2 provides an overview of studies that discussed car ownership models and effective variables in the international context. This table indicates the authors' names, units of analysis, employed methods, studied countries and explanatory variables.

Most of the methodologies used for these studies have taken the analytical approach. In comparison with numerical works, few studies have been conducted on descriptive methods. Iran, as one of the developing countries in the Middle East, had explosive growth in car ownership in recent years. Therefore, identification of factors affecting the tendency of people to use private vehicles and car ownership changes in the future are always important. So the use of appropriate and effective models will be the main point in further society plans.

We have used the data from different sources such as available data from Comprehensive Transportation studies and some papers and thesis that focused on car ownership modelling. The Iranian's government conducts a national census every 10 years. The census includes questions on household composition, housing stock, education, and car ownership for each city. On the other hand, each city has its own transportation studies. The investigations are concentrated in Kerman, Mashad, Yazd, Isfahan, Tehran and Qazvin. All these cities were chosen because of the accessibility of data.

\section{The Case of Iran}

The relationship between per capita car ownership and GDP for some cities of the Middle East indicates that Iran was allotted a tiny part in comparison with half the countries (Fig. 1). Even though car ownership per capita in Iran has shown steady growth till 1978, it experienced a drop for almost two decades, because of war, global political, economic sanctions and a significant growth in birth rate. Since 1998 the rising behaviour has been observed again with even a higher rate. It can thus be concluded that the per capita car ownership, quite expectedly, has had a growth trend which was temporarily halted for two decades due to the very disturbing condition of war (Fig. 2). The same trending changes in densely populated cities of Iran such as Tehran, Tabriz, Shiraz, Esfahan and Mashhad are observed (Fig. 3) (Comprehensive Transportation Study of Esfahan, 2001). However, in smaller cities and rural areas, per capita car ownership has continued its slow growth. Furthermore, one of the most important factors which increases the willingness of households to buy a car is the increase in car production and diversity. Economic growth and development of the automotive industry has led to a sharp jump in car production from 2000 to 2011 (Fig. 4). But in 2012 the rate of growth in car production decreased about 40 percent. Due to a sudden rise in car parts price and high inflation, despite moderate growth of population. This trend has continued until now and is predicted to continue until 2030 (Comprehensive Transportation Study of Kerman, 2012). 
Table.2. Overview of international car ownership studies

\begin{tabular}{|c|c|c|c|c|c|c|c|c|}
\hline \multirow[b]{2}{*}{ Author(s) } & \multirow[b]{2}{*}{ year } & \multirow[b]{2}{*}{ Models } & \multirow[b]{2}{*}{$\begin{array}{l}\text { Level of } \\
\text { Analysis }\end{array}$} & \multirow[b]{2}{*}{$\begin{array}{l}\text { Countries } \\
\text { Analyzed }\end{array}$} & \multicolumn{4}{|c|}{ Variables } \\
\hline & & & & & $\begin{array}{l}\text { Socio- } \\
\text { Economic } \\
\text { Factors }\end{array}$ & $\begin{array}{c}\text { Land } \\
\text { Use } \\
\text { Factors }\end{array}$ & $\begin{array}{c}\text { Behavieral } \\
\& \\
\text { Attitudinal } \\
\text { Factors }\end{array}$ & $\begin{array}{c}\text { Public } \\
\text { Transport } \\
\text { Factors }\end{array}$ \\
\hline Oakil et al. & 2016 & $\begin{array}{l}\text { Logistic } \\
\text { Regression }\end{array}$ & Disagg. & Netherlands & $\times$ & $\times$ & & \\
\hline $\begin{array}{l}\text { McGoldrick } \\
\text { and Caulfield }\end{array}$ & 2015 & Multinomial Logit & Disagg. & Ireland & $\times$ & & & $\times$ \\
\hline Verma & 2015 & Descriptive & Disagg. & India & $\times$ & & $\times$ & $x$ \\
\hline Zhang et al. & 2014 & $\begin{array}{l}\text { Aggregate and } \\
\text { Exhaustive } \\
\text { CHAID } \\
\text { Analysis }\end{array}$ & Disagg. & Japan & $\times$ & $\times$ & & \\
\hline Begiawan et al. & 2014 & $\begin{array}{l}\text { Descriptive } \\
\text { Analysis }\end{array}$ & Disagg. & $\begin{array}{l}\text { China, } \\
\text { Indonesia, } \\
\text { Japan, } \\
\text { Lebanon, } \\
\text { Netherlands, } \\
\text { Taiwan, USA }\end{array}$ & $\times$ & & $\times$ & $x$ \\
\hline Liu et al. & 2014 & Multinomial Logit & Disagg. & USA & $\times$ & $\times$ & & \\
\hline $\begin{array}{l}\text { Ritter and } \\
\text { Vance }\end{array}$ & 2013 & Multinomial Logit & Disagg. & Germany & $\times$ & $\times$ & & $x$ \\
\hline Guo & 2013 & Nested Logit & Disagg. & USA & $\times$ & $\times$ & & \\
\hline Azadeh et al. & 2012 & $\begin{array}{l}\text { Neural Network- } \\
\text { Fuzzy Linear } \\
\text { Regression }\end{array}$ & Agg. & Iran & $\times$ & $\times$ & & \\
\hline $\begin{array}{l}\text { Rashidi and } \\
\text { Mohammadian }\end{array}$ & 2011 & Dynamic Model & Disagg. & USA & $\times$ & $x$ & & $x$ \\
\hline De Jong et al. & 2009 & Dynamic Models & Agg. & Netherlands & $\times$ & & & \\
\hline $\begin{array}{l}\text { Matas and } \\
\text { Raymond }\end{array}$ & 2008 & $\begin{array}{l}\text { Ordered Probit, } \\
\text { Multinumial Logit }\end{array}$ & Disagg. & Spain & $\times$ & $\times$ & & $\times$ \\
\hline $\begin{array}{l}\text { Potoglou and } \\
\text { Kanarglou }\end{array}$ & 2008 & Multinumial Logit & Disagg. & Canada & $\times$ & $\times$ & & $\times$ \\
\hline Dargay et al. & 2007 & Gompertz model & Agg. & Worldwide & $x$ & & & \\
\hline Whelan & 2007 & $\begin{array}{l}\text { Hierarchical } \\
\text { Dogit, Binary } \\
\text { Dogit }\end{array}$ & Disagg. & Britain & $\times$ & & & \\
\hline Hsu et al. & 2007 & $\begin{array}{l}\text { Poisson } \\
\text { Regression }\end{array}$ & Disagg. & Taiwan & $\times$ & & & $x$ \\
\hline Clark & 2007 & $\begin{array}{l}\text { Geographically } \\
\text { Weighted } \\
\text { Regression }\end{array}$ & Agg. & England & $\times$ & & & \\
\hline Ögüt & 2006 & Fuzzy Regression & Agg & Turkey & $x$ & $x$ & & \\
\hline Ögüt & 2004 & $\begin{array}{l}\text { S-Curve models } \\
\text { (logistic, power } \\
\text { growth and } \\
\text { Gompertz curves) }\end{array}$ & Agg. & Turkey & $\times$ & & & \\
\hline $\begin{array}{l}\text { Dissanayake } \\
\text { and Morikawa }\end{array}$ & 2002 & Nested Logit & Disagg. & Thailand & $x$ & $x$ & & $\times$ \\
\hline Kain & 2001 & Descriptive & Agg. & Iran, England & $x$ & $x$ & & $x$ \\
\hline Dargay & 2001 & Dynamic model & Disagg. & England & $\times$ & & & \\
\hline $\begin{array}{l}\text { Dargay and } \\
\text { Gately }\end{array}$ & 2001 & Gompertz model & Agg. & Worldwide & $\times$ & & & \\
\hline Ryan and Han & 1999 & Multinumial Logit & Disagg. & USA & $\times$ & & & \\
\hline $\begin{array}{l}\text { Bhat and } \\
\text { Pulugurta }\end{array}$ & 1998 & $\begin{array}{l}\text { Ordered Logit, } \\
\text { Multinumial Logit }\end{array}$ & Disagg. & $\begin{array}{l}\text { Netherlands, } \\
\text { USA }\end{array}$ & $x$ & & & \\
\hline Button et al. & 1993 & $\begin{array}{l}\text { Quasi-Logestic } \\
\text { Regression }\end{array}$ & Agg. & Worldwide & $\times$ & & & \\
\hline Said & 1992 & Linear regression & Disagg. & Kuwait & $\times$ & & & \\
\hline
\end{tabular}




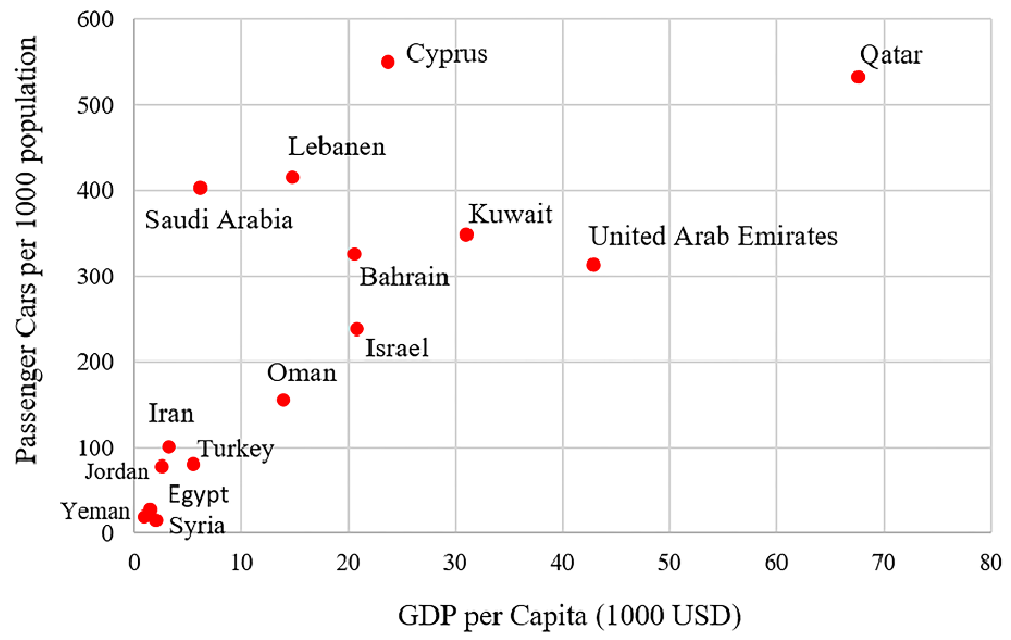

Figure 1. The relation between car ownership and GDP in the some Middle East countries (World Bank, 2006)

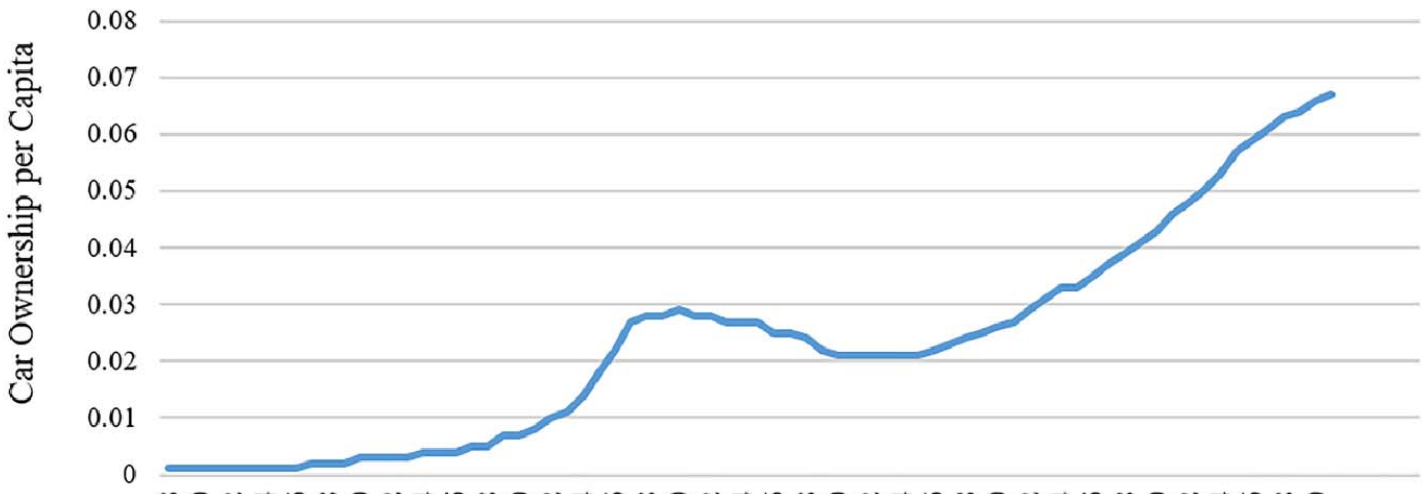

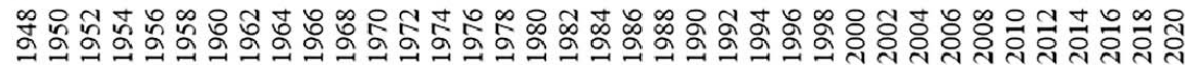

Year

Figure 2. Car ownership variation in Iran (Comprehensive Transportation Study of Esfahan, 2001)

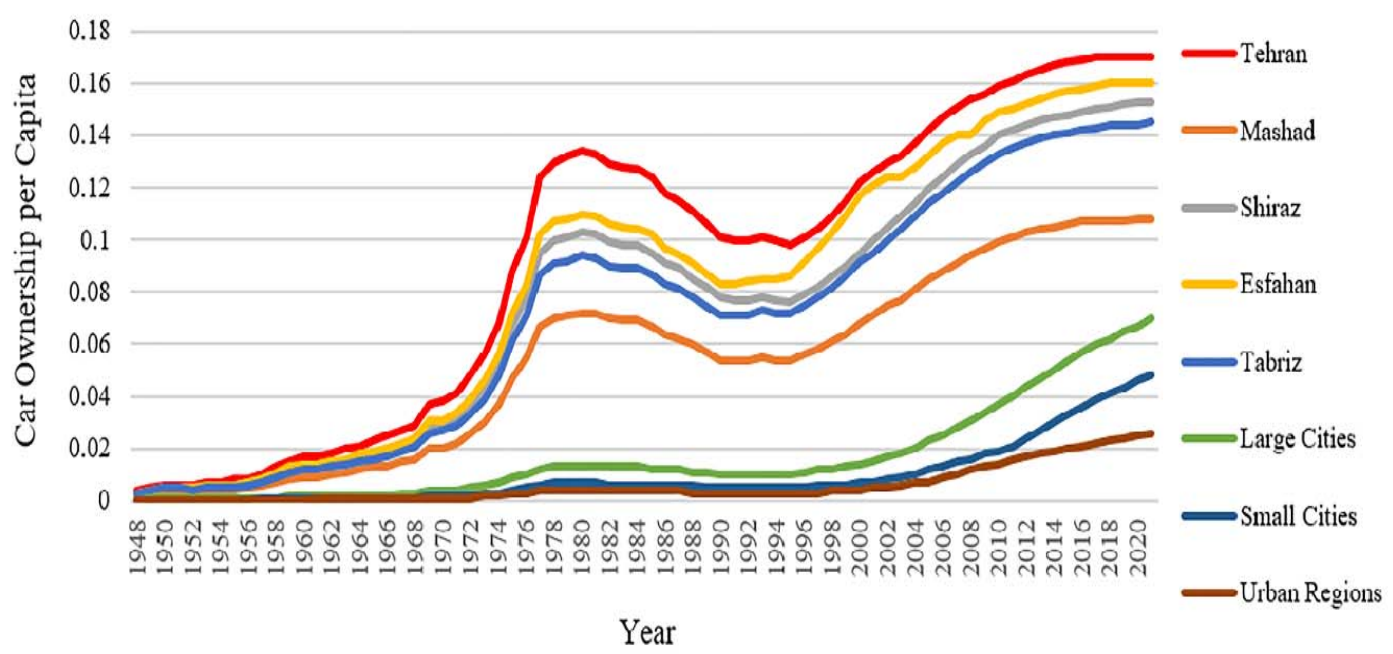

Figure 3. Comparison of car ownership variation in some cities of Iran (Comprehensive Transportation Study of Esfahan, 2001) 


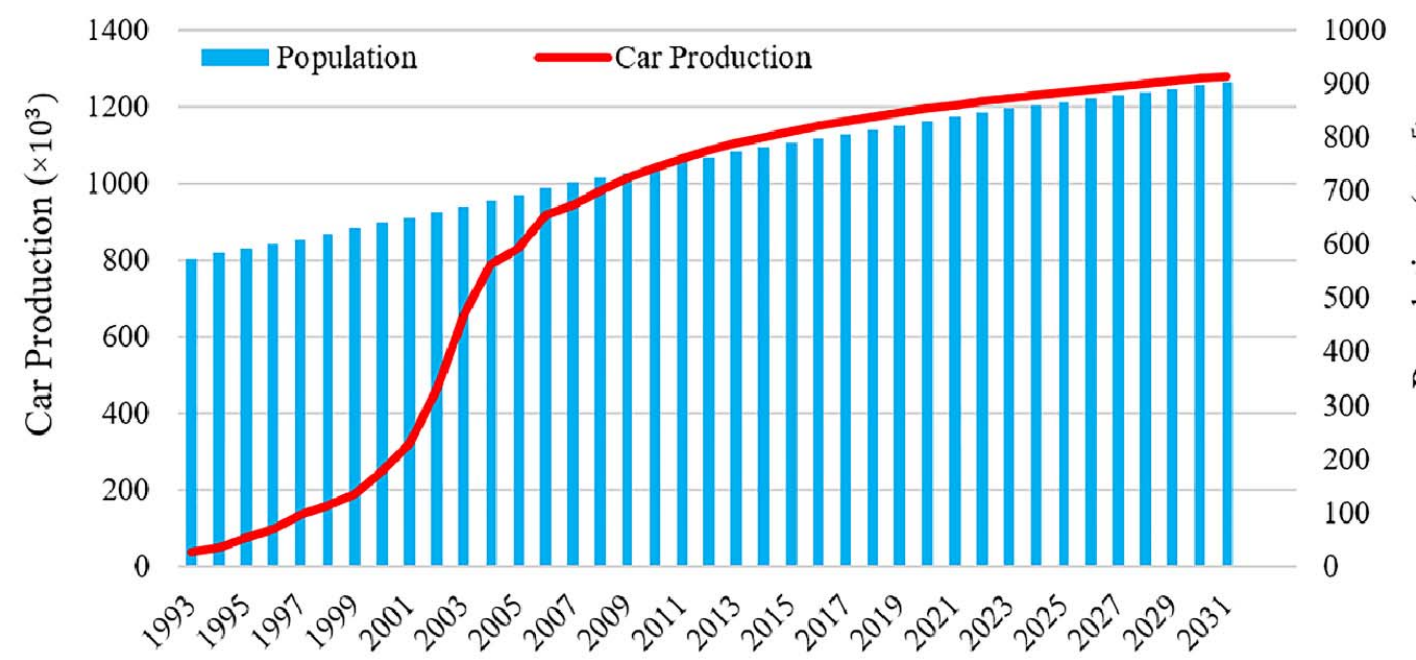

Year

Figure 4. Car production and population trend in Iran (Comprehensive Transportation Study of Kerman, 2012)

The most important factor in the model of car ownership is household income which is very difficult to gather from households. Therefore, it may be necessary to substitute the income variable by one or more variables which is more accessible, the most common alternative variable being per capita GDP. Figure 5 illustrates per capita car ownership and GDP trend in Iran for the past four decades. For a period of about 34 years (from 1981 to 2014), except for a few years, their trends are similar.

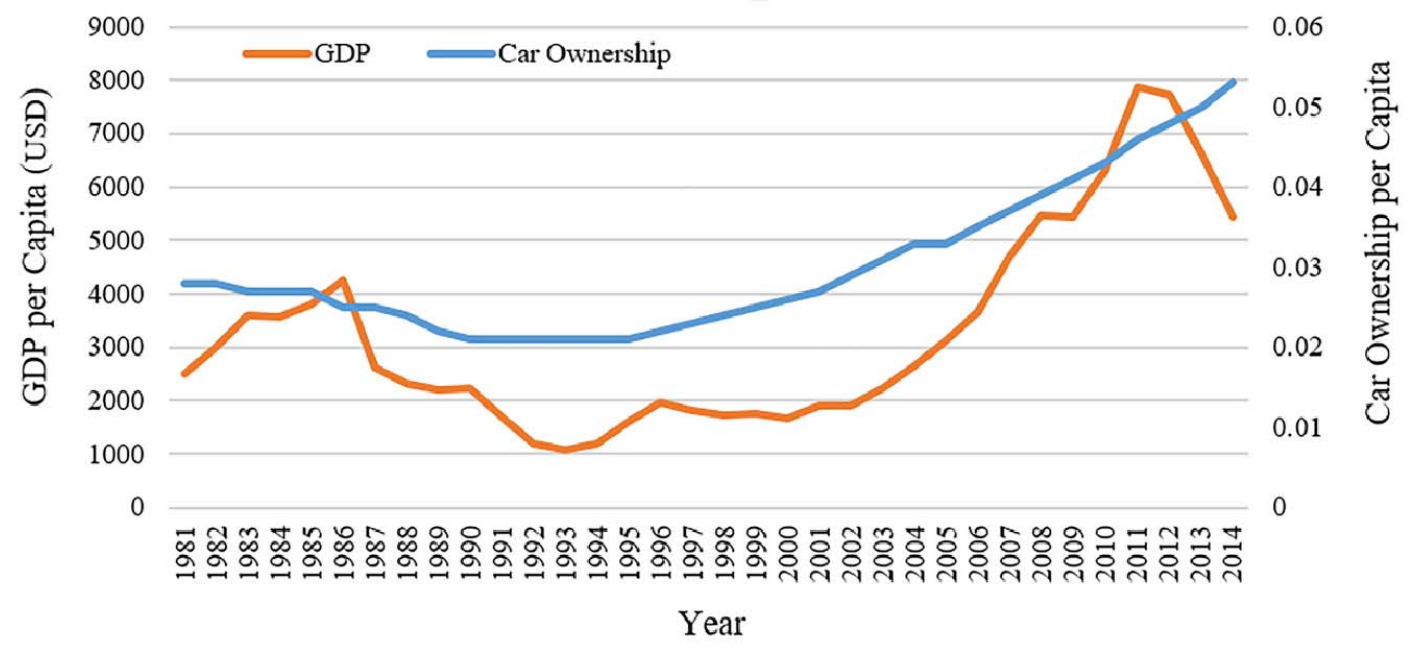

Figure 5. Per capita car ownership and GDP trend in Iran from 1981 to 2014

In Comprehensive Transportation Studies of Iran, (CTSI) (2008), the country was divided into 56 traffic zones. The data were gathered in 2007. Per capita car ownership calculated up is the ratio of number of vehicles to the households in each zone. The population of people with cars would be equal to multiply this ratio by the total population. Between 2005 and 2006, GDP per capita grew at an annual rate of 4 percent which is assumed to be constant for next 20 years.

Detailed OD data were gathered for Comprehensive Transportation Study of Mashad (CTSM) in 1994, where the city was divided into 141 traffic zones. Accordingly, Kermanshah and Ghazi (2001) proposed a Nested Logit Model using a 25\% random sample from MCTS data. Then they developed a two-level model of car ownership by simple multinomial logit models. In Each household, socioeconomic conditions such as the number of household employed members and their income level influence people's desire to own more than one car. The type of the job was important as well. Teachers or governmental employees often had only one car. Furthermore, the existence of males, the age of the 
oldest child, and household size were significant factors to purchase a car. They concluded that the public transport conditions and household lifestyles affected car ownership (Kermanshah and Ghazi, 2001).

In 2001, the local government, calculated average car ownership per capita in Esfahan. They used Tehran's 1991 CTST (Comprehensive Transportation study of Tehran) information as the base data in trend-based method. They estimated car ownership in Esfahan at each zone, according to the assumption of the limited imports of cars to the country on the one hand, and having cars with a life of 25 years in the vehicle fleet on the streets on the other hand. Afterward, they predicted private car ownership using the number of cars to be produced (Comprehensive Transportation Study of Esfahan, 2008).

In 2008, a new CTSM was conducted by local government. They converted disaggregate data to aggregate, and they then used aggregate variables as independent variables for modelling. In this study, three groups of models were used: a trend base model, regression Models and discrete choice models. At first, the linear regression model was a simplest model that they presented. In the next step, they used Direct and Non-Direct Nonlinear models. On the contrary to the direct models which predicted car ownership per capita, Non-Direct models indicated the percentage of households with different number of cars for each zone. They applied Multinomial logistic and ordinal regression as discrete choice models to predict car ownership but ordinal regression did not have good response and it was ignored. For making Trend base model, they determined the type of cars for which the car ownership should be made and city's population were estimated for past and future. Finally, they computed car ownership per capita of Mashad according to the share of Mashad's population, the number of licensed of vehicles and the annual produced cars to the whole country (Comprehensive Transportation Study of Mashad, 2008).

Finally, Kerman investigation was conducted in 2011, a Trend base method was used for car ownership modelling. In this method, ownership per capita at Kerman was estimated according to the statistic and history of car manufacturing in Iran, the continuation assumption of car manufacturing in future and calculation of the share of Kerman in car production of the country. The proportion of Kerman's population to the whole country was used in order to ascertain the share of this city in total sedans produced in the country. New cars were distributed between different areas of the city with determination of Kerman's total contribution to the number of new cars in each year (Comprehensive Transportation Study of Kerman, 2011).

A Logistic Regression model was created for Yazd in 2011. The independent variables were household size, employment ratio and women owning a driving license ratio. They did not use residential land unit price because this variable had non-uniform changes in traffic areas and even in each zone so it generated inappropriate goodness of fit in the model (Comprehensive Transportation Study of Yazd, 2011).

The logistic function index of the car ownership in household level at Ghazvin in 1980 was low in the city due to the poor economic condition of citizens, luxury cars and also the low number of purchasable vehicles. Moreover, in 1980s and 2000s this amount had an abrupt growth and much lower amount of car ownership in 2010 s in comparison with the previous decade was eventually anticipated due to the car saturation of the city and elimination of personal car from the government list of luxury products category. Finally, in 2012, a logistic model was implemented in 12 traffic areas of Qazvin. The data of 113 internal traffic zones of Qazvin were accumulated in the form of 12 traffic areas in order to aggregate the information and enhancement of modelling accuracy. Then the information of each region and vehicle ownership per capita in possession of each household in areas were used for modelling. It should be noted that in the stage of travel demand modelling, the average car ownership per capita for each traffic zone will be equivalent to the average of this amount in an area where the mentioned traffic area has been located in. Baseline variables used in this model were average household size, the proportion of employees and socio-economic classifications in each traffic area which have been accomplished based on the average price per meter of land. The average car ownership per capita of the vehicle in the city of Qazvin in the current situation was estimated to be 0.69 vehicle per household which in comparison with other parts of the country had a relatively large number that represented an appropriate living conditions in comparison with other parts of the city and citizens of Qazvin. The developed logistic model predicted the values of private ownership of vehicles in different traffic areas in the status quo and coming years perfectly (Comprehensive Transportation Study of Qazvin, 2012).

In 2012, Ghodratabadi used Tehran's data gathered in 2005 by Government. According to the models made with aggregate data, he concluded that the Geographically Weighted Regression (GWR) and the method of Quarmby and Bates produce better results than the linear regression method. When he used disaggregate models, he found out discrete choice models such as Multinomial and Nested logit improved $\left(\rho^{2}\right)$ in comparison with in count regression method. Although increased tax value of the lands, 
number of young people who had a driving license and highly educated in each household or zone, expanded car ownership. , he saw that increasing in population density decreases car use.

Table 3 summarized the modelling approaches used in these previous Iranian studies, most of which were explained above. The table is meant to provide a perspective of the methods and variables employed in Iranian car ownership modelling.

\section{Discussion}

Middle East has always been considered as an important economic, geographical and political zone in Asia. The achievement of sustainable transportation and stronger desire to car ownership reduction are much necessary for future urban planning. Trying to investigate and forecast car ownership in this area is been limited to a few studies. However, the growth of negative consequences of using private vehicles has resulted in further requirement of deeper research in order to reach more effective models.

In comparison with other countries in the Middle East's tremendous progress can be seen in various cities of Iran. It can be argued that these investigations can be among the best studies in the Middle East that are relatively able to explain the car ownership changing rate. However, they are still not sufficient, because we do not have enough empirical works. Furthermore, the limitation of case studies and methods leads to weak results.

For most of the cities in Iran the basic reasons of increase in tendency of owning a car are unclear. Accordingly, we need more studies in comparison with international studies and what has been in Iran in order to offer more efficient solutions for avoiding private car usage. There are different cities in Iran with their own specific and distinct cultural, geographical and economic structure. Therefore, we have to use appropriate models, which are much closer to reality to investigate car ownership. According to the analysis presented in this paper, most car ownership models are done for highly populated towns, e.g. the provincial capitals. Since investigations on intermediate and less populated cities are negligible, we have a blur view to the variables affecting the willingness of people to use private car in these cities.

The most fundamental car ownership modelling problem is the absence or lack of access to required data in Iran. Socioeconomic variables are among the commonly used parameters in the models calibrated in Iran. The impossibility of estimating real income or wage for individuals results in usage of alternatives such as GDP or residential land unit price (Dargay and Gately, 2001; Ögüt, 2004). In Comprehensive Transportation Studies of Iran (CTSI) (2008), GDP was the only variable used, however, obviously GDP is not adequate to predict car ownership. Age, employment, population, gender, household size, household size, level of educations, having driving license and children are significant variables that observed in the Middle East models too (Said, 1992; Dargay and Gately, 2007; Ögüt, 2006; Azadeh et al., 2012; Begiawan et al., 2014). According to the aggregate or disaggregate data, appropriate models were utilized in different forms in each city.

Inhabitants' nationality, rate of immigration and economic factors such as the fuel price, tax values and parking fees were not considered in modelling, while as Said (1992) and Manski (1983) indicated, some of these variables may be effective on car ownership prediction in the Middle East.

The relationship between car ownership and land use is undeniable, as land use planning can reduce personal car use and encourage sustainable travels. Thus, disregarding the effect of land use variables such as population and employment densities, block length, street network connectivity, distance to the CBD, area, number of signalized and unsignalized intersections and many other factors are the main weaknesses in the proposed models in Iran. The Middle-Eastern car ownership studies often do not focus on land use issues either.

Failure to assess accessibility of public transport and the quality of private transport led to a vague vision about impact of these factors on level of car ownership in future. Behavioural analysis almost has not been studied in any Iranian researches. However, the culture and behavioural characteristics of individuals have a significant impact on choosing travel mode and use of private vehicles. These findings are consistent with that of Begiawan et al. (2014), who attempted to examine these variables in Lebanon.

Most urban transportation models aimed to predict rate of car ownership. In prediction models, aggregate data are preferred to data of household and individual level because results will be closer to reality.

Trend-based methods comprise the main models to predict car ownership in different cities and even the country. Growth in GDP, auto productions and population are the variables in these methods used in Iran and its cities, like Mashad, Kerman and Esfahan. In addition to regression models which were frequently used in Mashhad, Yazd, Tehran and some studies in the Middle-Eastern cities, such as those addressed by Ögüt $(2004 ; 2006)$ and Azadeh et al. (2012). Other models such as discrete choice models have also been applied in the recent studies. 


\begin{tabular}{|c|c|c|c|c|c|c|c|c|c|}
\hline & $\approx$ & 古 & 营㺃 & $\overrightarrow{\hat{\sigma}}$ & ठ̊. & ల్లె & 羿 & के & 웅 \\
\hline 惢 & 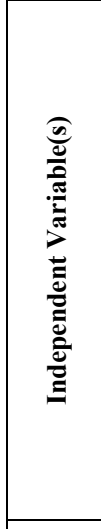 & 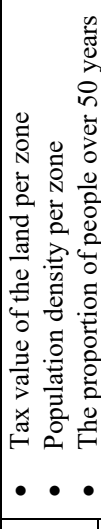 & 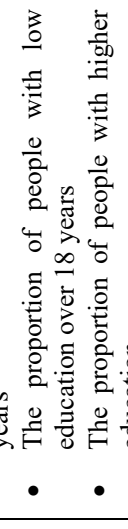 & 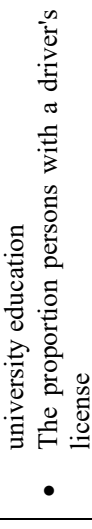 & 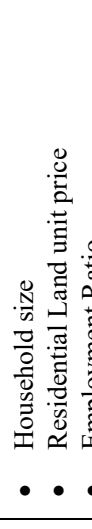 & 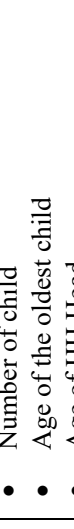 & 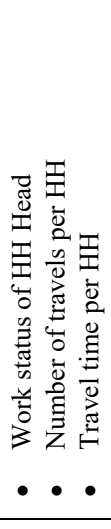 & 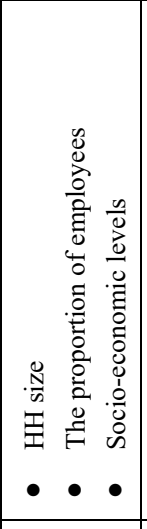 & 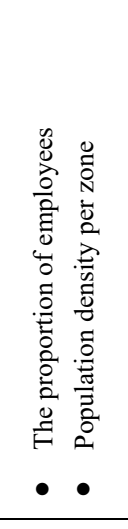 \\
\hline & 惫 & 善 & 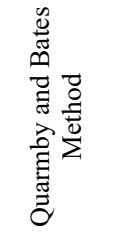 & 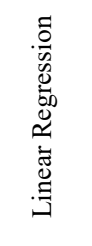 & 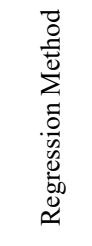 & 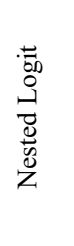 & 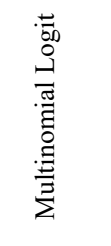 & 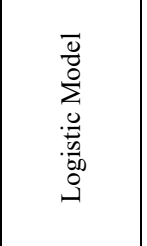 & 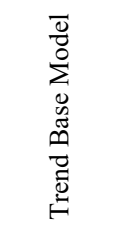 \\
\hline & 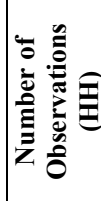 & & 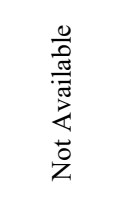 & & & 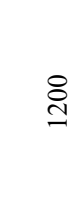 & & 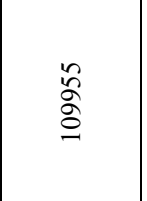 & 志 \\
\hline & 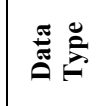 & & 然高高 & & & 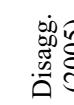 & & 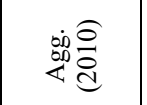 & 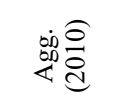 \\
\hline \multirow{5}{*}{ 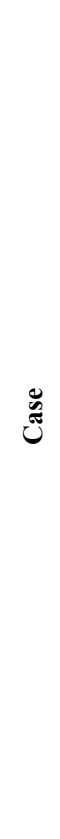 } & 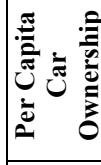 & & & $\stackrel{7}{0}$ & & & & $\frac{0}{0}$ & $\stackrel{n}{a}$ \\
\hline & 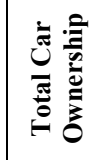 & & & 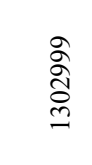 & & & & 总 & $\begin{array}{l}\infty \\
\alpha^{\infty} \\
\text { a }\end{array}$ \\
\hline & 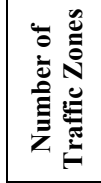 & & & : & & & & $\stackrel{m}{=}$ & $\stackrel{8}{7}$ \\
\hline & 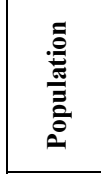 & & & $\begin{array}{l}\text { F } \\
\text { d } \\
\text { d }\end{array}$ & & & & 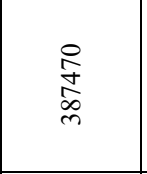 & $\begin{array}{l}\frac{a}{+} \\
\frac{\infty}{n}\end{array}$ \\
\hline & $E$ & & & 鬓 & & & & $\begin{array}{l}\text { 禀 } \\
\text { \& }\end{array}$ & 焉 \\
\hline \multicolumn{2}{|c|}{ 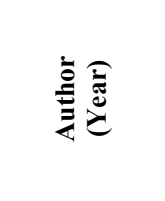 } & & & 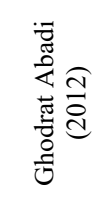 & & & & 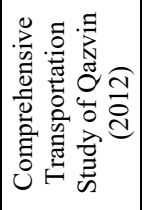 & 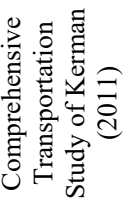 \\
\hline
\end{tabular}




\begin{tabular}{|c|c|c|c|c|c|c|c|}
\hline î. & $\bar{n}$ & $\begin{array}{l}\tilde{\text { aे }} \\
\text { and }\end{array}$ & 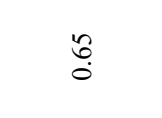 & $\begin{array}{l}\stackrel{2}{0} \\
\vdots\end{array}$ & $\stackrel{\infty}{\stackrel{\infty}{0}}$ & 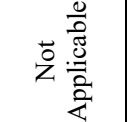 & 亏े \\
\hline 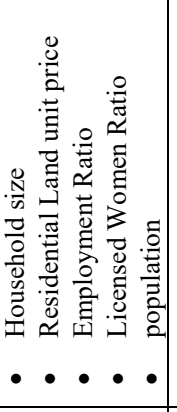 & 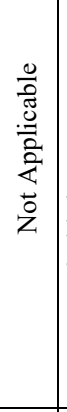 & 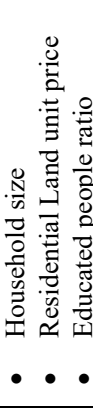 & 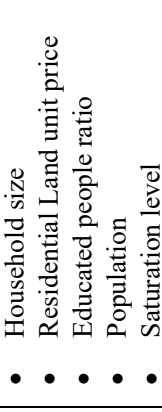 & 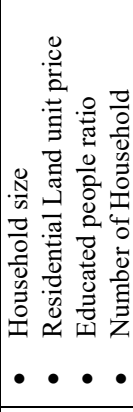 & 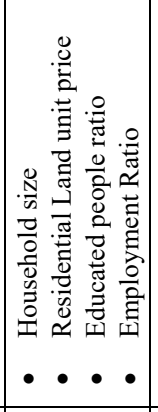 & 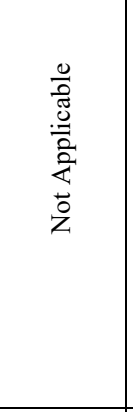 & 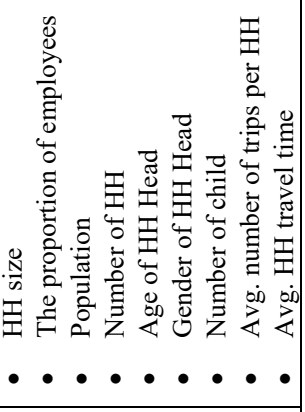 \\
\hline 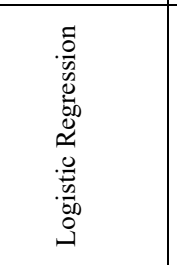 & 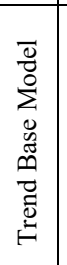 & 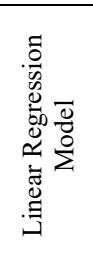 & 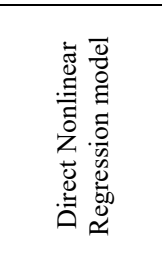 & 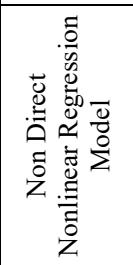 & 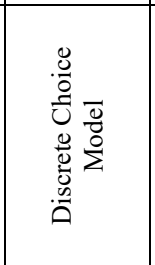 & 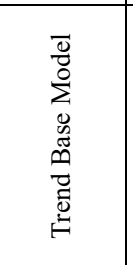 & 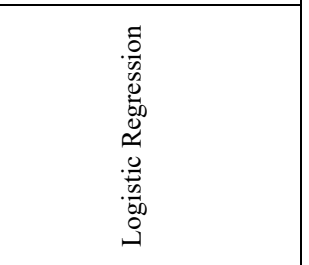 \\
\hline 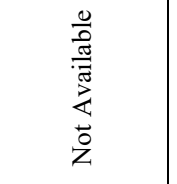 & & & 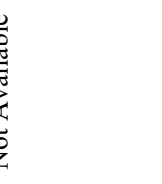 & & 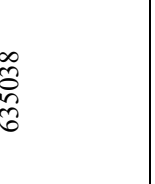 & 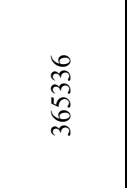 & d \\
\hline 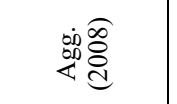 & & & $\begin{array}{l}\text { \&े } \\
\stackrel{d}{d}\end{array}$ & & 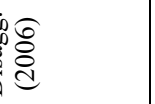 & 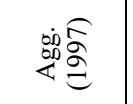 & 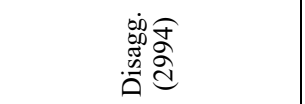 \\
\hline 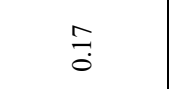 & \multicolumn{5}{|c|}{$\stackrel{n}{=}$} & $\stackrel{\Xi}{=}$ & $\begin{array}{l}\vec{n} \\
\tilde{0}\end{array}$ \\
\hline 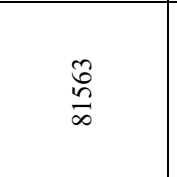 & \multicolumn{5}{|c|}{ 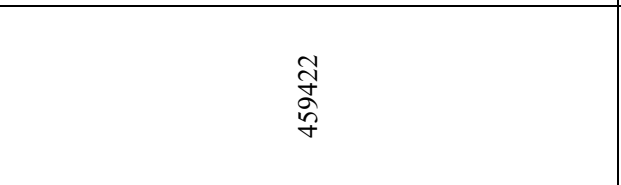 } & 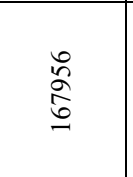 & 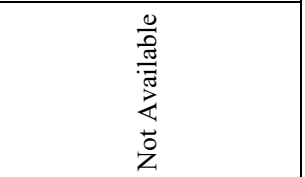 \\
\hline q & \multicolumn{5}{|c|}{$\tilde{\hat{n}}$} & $\stackrel{\infty}{\stackrel{\infty}{\rightarrow}}$ & $\Xi$ \\
\hline 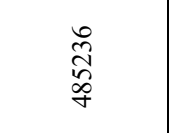 & \multicolumn{5}{|c|}{$\begin{array}{l}\tilde{\mathrm{d}} \\
\stackrel{\widetilde{\sigma}}{\mathrm{N}}\end{array}$} & 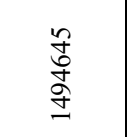 & $\begin{array}{l}\text { ठे } \\
\text { ठ̀े } \\
\text { ? }\end{array}$ \\
\hline $\begin{array}{l}\underset{\mathbb{Z}}{\nu} \\
.\end{array}$ & \multicolumn{5}{|c|}{ 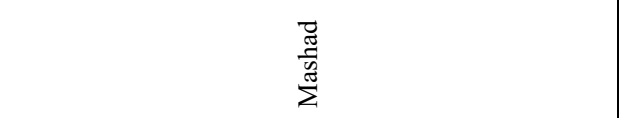 } & $\begin{array}{l}\text { 志 } \\
\text { 矛 } \\
\text { 至 }\end{array}$ & 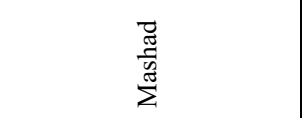 \\
\hline 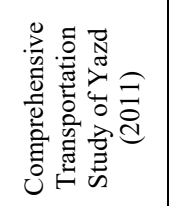 & \multicolumn{5}{|c|}{ 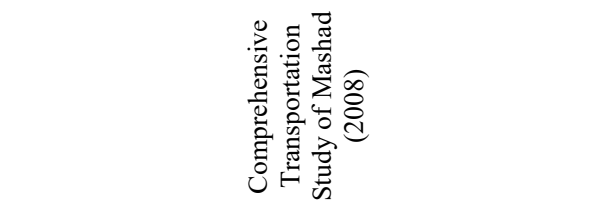 } & 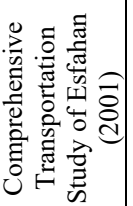 & 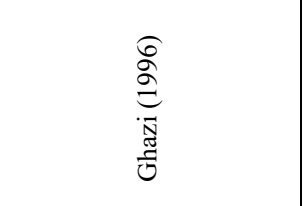 \\
\hline
\end{tabular}


Complexity of the employed models is increasing through time, which in case of correct model organization and proper validation will lead to a better portrait of vehicle ownership (Comprehensive Transportation study of Mashad, 2008; Ghodrat Abadi, 2012). From the modelling point of view, discrete choice models have grown during recent years. Before that, simpler modelling approaches like regression, including different types, have been the prominent methods. Except Turkish (Ogut, 2004; 2006) and to some extent Egyptian studies, very limited good-quality studies have been undertaken in other MiddleEastern countries. Nevertheless, it would still be useful for all countries in the region to use disaggregate data for more complex modelling methods.

Statuesque of Iranian car ownership research and modelling is not an exact representative of what is going on in the region, but presenting a comparative study can help researchers and transport planners to ascend from initial level of exploratory case studies to a more advanced level of general theoretical models. Except Dargay and Gately's research (2001), no other comparative study between car ownership in Iran and other developing and developed countries has been conducted.

\section{Conclusion}

According to the last decades researches, car use and travel behaviour are associated with car ownership directly. Therefore, like in most developing countries, along with the growth of car ownership, the overall amount of modal share of car use which is the most dominant modes of transport in Iran (Comprehensive Transportation Study of Iran, 2008), has almost increased substantially. Within 11 years, car use has increased by a half or more in most of the metropolitans of Iran such as Tehran: from $29 \%$ in 2002 (Ghodrat Abadi, 2012) to 67.7\% in 2013 (Tehran Comprehensive Transportation and Traffic Studies Company, 2014). Controlling and managing travel patterns and car use to reduce unsustainability in the Iranian cities, have become a critical issue in the country because negative consequences of excessive use of private car such as using non-renewable fuels, a dramatic increase in the rate of traffic-related deaths, social isolation, the disconnection of community, the rise in obesity, the generation of air or noise pollution, urban sprawl, and urban decay (Kay, 1997) are non-negligible. Use of appropriate car ownership models with effective variables to capture and predict their change has gained more momentum for further society plans.

Based on this literature survey conducted on car ownership in Iran, the following points would summarize the important parts of the studies, which were discussed above:

- In spite of many studies conducted on major heavily populated cities, little attention has been paid to less populated cities. Undoubtedly, it is not suitable to compare them with each other because they have different urban forms, densities and economic activities. However, undertaking such studies may provide a new perspective about the nature and essence of car ownership and availability in small and medium-sized cities.

- Car ownership models have slightly changed notably with a trend from regression models towards discrete choice models. However, the concentration of majority of researches are still on linear regression models and the share of complex modelling methods is not yet enough relative to the complex realities of the society. Thus, applying more complex statistical and modelling methods are highly recommended.

- The data applied for modelling are mostly on an aggregate level, while disaggregate data are very less exploited. Therefore, developing comprehensive disaggregate models, which are much closer to reality to investigate car ownership is impossible and the final results of the investigations are not accurate. Hence, improving the quality of depth of surveys and data collection activities would have enormous effect on the quality of the future car ownership models.

- Socio-economic factors are generally the only variables considered in modelling, where income, as one of the most important variables in this group, is not usually available and thus, at times, proxies were used. Furthermore, there is a lack of studies related to car ownership and accessibility and efficiency of transport infrastructure and public transport. Discussing about land use, urban transformation, e.g. urban sprawl and personal preferences seem to be forgotten by the researches.

The lack of model-based researches due to the data unavailability resulted in large gaps in the literature. This is particularly true about comprehensive transportation studies integrating numerical and descriptive studies. 
For future studies, we suggest using disaggregate and aggregate data to create a variety of models with behavioural and economic variables, land use characteristics and public transport factors. These can also be applied to medium and small cities, where performing comparative studies with other countries will determine the effective variables in car ownership and certainly have a significant impact on our models.

\section{References}

1. Allanson, E.W. (1982) Car ownership forecasting (Vol. 1). Routledge.

2. Azadeh, A., Neshat, N., Rafiee, K. and Zohrevand, A.M. (2012) An adaptive neural network-fuzzy linear regression approach for improved car ownership estimation and forecasting in complex and uncertain environments: the case of Iran. Transportation Planning and Technology, 35(2), 221-240.

3. Bagley, M.N. and Mokhtarian, P.L. (2002) The impact of residential neighbourhood type on travel behavior: a structural equations modelling approach. The Annals of regional science, 36(2), pp.279297.

4. Belgiawan, P.F., Schmöcker, J.D., Abou-Zeid, M., Walker, J., Lee, T.C., Ettema, D.F. and Fujii, S. (2014) Car ownership motivations among undergraduate students in China, Indonesia, Japan, Lebanon, Netherlands, Taiwan, and USA. Transportation, 41(6), 1227-1244.

5. Bento, A.M., Cropper, M.L., Mobarak, A.M. and Vinha, K. (2005) The effects of urban spatial structure on travel demand in the United States. Review of Economics and Statistics, 87(3), 466-478.

6. Bhat, C.R. and Pulugurta, V. (1998) A comparison of two alternative behavioural choice mechanisms for household auto ownership decisions. Transportation Research Part B: Methodological, 32(1), 61-75.

7. Button, K., Ngoe, N. and Hine, J. (1993) Modelling vehicle ownership and use in low income countries. Journal of Transport Economics and Policy, 27(1), 51-67.

8. Chiou, Y.C., Wen, C.H., Tsai, S.H. and Wang, W.Y. (2009) Integrated modelling of car/motorcycle ownership, type and usage for estimating energy consumption and emissions. Transportation Research Part A: Policy and Practice, 43(7), 665-684.

9. Clark, S.D. (2007) Estimating local car ownership models. Journal of Transport Geography, 15(3), 184-197.

10. Comprehensive Transportation Study of Esfahan (2001) Car ownership model. Esfahan: The Municipality of Esfahan. (83-05).

11. Comprehensive Transportation Study of Iran (2008) Demand Forecasting (Estimating the Economic and Social Variables). Department of Transportation. (p3j2f2).

12. Comprehensive Transportation Study of Kerman (2012) Car ownership model. Kerman: The Municipality of Kerman. (AR-KRM-001-P-004/3).

13. Comprehensive Transportation Study of Mashad (2008) Car ownership model. Mashad: The Municipality of Mashad. (34-300).

14. Comprehensive Transportation Study of Qazvin (2012) Car ownership model. Qazvin: The Municipality of Qazvin. (3-9).

15. Comprehensive Transportation Study of Yazd (2011) Car ownership model. Yazd: The Municipality of Yazd.

16. Dargay, J.M. (2001) The effect of income on car ownership: evidence of asymmetry. Transportation Research Part A: Policy and Practice, 35(9), 807-821.

17. Dargay, J. and Gately, D. (2001) Modelling global vehicle ownership. In Proceedings of the Ninth World Conference on Transport Research (pp. 22-27).

18. Dargay, J., Gately, D. and Sommer, M. (2007) Vehicle ownership and income growth, worldwide: 1960-2030. The Energy Journal, 143-170.

19. De Jong, G.C. and Kitamura, R. (2009) A review of household dynamic vehicle ownership models: holdings models versus transactions models. Transportation, 36(6), 733-743.

20. Dieleman, F.M., Dijst, M. and Burghouwt, G. (2002) Urban form and travel behaviour: micro-level household attributes and residential context. Urban Studies, 39(3), pp.507-527.

21. Dissanayake, D. and Morikawa, T. (2002) Household travel behaviour in developing countries: nested logit model of vehicle ownership, mode choice, and trip chaining. Transportation Research Record: Journal of the Transportation Research Board, (1805), 45-52.

22. Domencich, T. and McFADDEN, D. (1972) A Disaggregated Behavioural Model of Urban Travel Demand. In Rep. No. CRA-156-2. Charles River Associates, Inc Cambridge, MA 02116.

23. Ellaway, A., Macintyre, S., Hiscock, R. and Kearns, A. (2003) In the driving seat: psychosocial benefits from private motor vehicle transport compared to public transport. Transportation Research Part F: Traffic Psychology and Behaviour, 6(3), 217-231. 
24. Ghodrat Abadi, M. (2012) Car ownership modelling. Tehran: Sharif University of Technology.

25. Gilbert, C.C. (1992) A duration model of automobile ownership. Transportation Research Part B: Methodological, 26(2), 97-114.

26. Goodwin, P.B. (1986) A panel analysis of changes in car ownership and bus use. Traffic engineering \& control, 27(10), 519-525.

27. Guo, Z. (2013) Does residential parking supply affect household car ownership? The case of New York City. Journal of Transport Geography, 26, 18-28.

28. Hsu, T.P., Tsai, C.C. and Lin, Y.J. (2007) Comparative analysis of household car and motorcycle ownership characteristics. Journal of the Eastern Asia Society for Transportation Studies, 7, 105-115.

29. Jensen, M. (1999) Passion and heart in transport-a sociological analysis on transport behaviour. Transport Policy, 6(1), 19-33.

30. Jong, G.D., Fox, J., Daly, A., Pieters, M. and Smit, R. (2004) Comparison of car ownership models. Transport Reviews, 24(4), 379-408.

31. Kain, J.F. and Beesley, M.E. (1965) Forecasting car ownership and use. Urban Studies, 2(2), 163185 .

32. Kain, J.F. (2001) A tale of two cities: relationships between urban form, car ownership and use and implications for public policy. Journal of Transport Economics and Policy, 31-70.

33. Kay, J.H. (1997) Asphalt nation: how the automobile took over America, and how we can take it back. Univ of California Press.

34. Kermanshah, M. and Kitamura, R. (1995) Effects of land use and socio-demographic characteristics on household travel pattern indicators. J. of Scientia Iranica, 2(3), 245-262.

35. Kermanshah, M. and Ghazi, F. (2001) Modelling automobile ownership decisions: A disaggregate approach. Scientia iranica, 8(1), 29-37.

36. Kumar, M. and Krishna Rao, K.V. (2006) A stated preference study for a car ownership model in the context of developing countries. Transportation Planning and Technology, 29(5), 409-425.

37. Lerman, S.R. (1979) The use of disaggregate choice models in semi-Markov process models of trip chaining behaviour. Transportation Science, 13(4), 273-291.

38. Liu, Y., Tremblay, J.M. and Cirillo, C. (2014) An integrated model for discrete and continuous decisions with application to vehicle ownership, type and usage choices. Transportation Research Part A: Policy and Practice, 69, 315-328.

39. Loukopoulos, P. (2005) Future urban sustainable mobility-Implementing and understanding the impacts of policies designed to reduce private automobile usage.

40. Manski, C.F. (1983) Analysis of equilibrium automobile holdings in Israel with aggregate discrete choice models. Transportation Research Part B: Methodological, 17(5), 373-389.

41. Matas, A. and Raymond, J.L. (2008) Changes in the structure of car ownership in Spain. Transportation Research Part A: Policy and Practice, 42(1), 187-202.

42. McGoldrick, P. and Caulfield, B. (2015) Examining the changes in car ownership levels in the Greater Dublin Area between 2006 and 2011. Case Studies on Transport Policy, 3(2), 229-237.

43. Meurs, H. (1990) Dynamic analysis of trip generation. Transportation Research Part A: General, 24(6), 427-442.

44. Mogridge, M.J.H. (1967) The prediction of car ownership. Journal of Transport Economics and Policy, 52-74.

45. Oakil, A.T.M., Manting, D. and Nijland, H. (2016) Determinants of car ownership among young households in the Netherlands: The role of urbanisation and demographic and economic characteristics. Journal of Transport Geography, 51, 229-235.

46. Ögüt, K.S. (2004) S-curve models to determine the car ownership in Turkey. ARI, The Bulletin of the Istanbul Technical University, 54(2).

47. Öğ̈̈t, K.S. (2006) Modelling car ownership in Turkey using fuzzy regression. Transportation planning and technology, 29(3), 233-248.

48. Paulley, N., Balcombe, R., Mackett, R., Titheridge, H., Preston, J., Wardman, M., ... and White, P. (2006) The demand for public transport: The effects of fares, quality of service, income and car ownership. Transport Policy, 13(4), 295-306.

49. Phang, S.Y. and Chin, A. (1990) An Evaluation of Car-Ownership and Car-Usage Policies in Singapore.

50. Potoglou, D. and Kanaroglou, P.S. (2008) Modelling car ownership in urban areas: a case study of Hamilton, Canada. Journal of Transport Geography, 16(1), 42-54. 
51. Rashidi, T.H. and Mohammadian, A.K. (2011) A dynamic hazard-based system of equations of vehicle ownership with endogenous long-term decision factors incorporating group decision making. Journal of Transport Geography, 19(6), 1072-1080.

52. Ritter, N. and Vance, C. (2013) Do fewer people mean fewer cars? Population decline and car ownership in Germany. Transportation Research Part A: Policy and Practice, 50, 74-85.

53. Ryan, J. and Han, G. (1999) Vehicle-ownership model using family structure and accessibility application to Honolulu, Hawaii. Transportation Research Record, Journal of the Transportation Research Board, 1676, 1-10.

54. Said, G.M. (1992) Modelling household car ownership in the Gulf States: the case of Kuwait. Journal of Transport Economics and Policy, 121-138.

55. Sinha, K.C. (2003) Sustainability and urban public transportation. Journal of Transportation Engineering, 129(4), 331-341.

56. Stasko, T.H., Buck, A.B. and Gao, H.O. (2013). Carsharing in a university setting: Impacts on vehicle ownership, parking demand, and mobility in Ithaca, NY. Transport Policy, 30, 262-268.

57. Tanner, J.C. (1963) Car and motorcycle ownership in the counties of Great Britain in 1960. Journal of the Royal Statistical Society. Series A (General), 276-284.

58. Tehran Comprehensive Transportation and Traffic Studies Company (2014), Selective statistics for transport and traffic in Tehran, 2013.

59. Verma, M. (2015) Growing car ownership and dependence in India and its policy implications. Case Studies on Transport Policy, 3(3), 304-310.

60. Whelan, G. (2007) Modelling car ownership in Great Britain. Transportation Research Part A: Policy and Practice, 113, 205-219.

61. World Bank (2006-2014) [online] Available from: http://data.worldbank.org. [ Accessed: 31April 2016]

62. Zhang, J., Yu, B. and Chikaraishi, M. (2014) Interdependences between household residential and car ownership behaviour: a life history analysis. Journal of Transport Geography, 34, 165-174. 